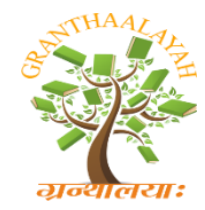

INTERNATIONAL JOURNAL OF RESEARCH GRANTHAALAYAH A knowledge Repository

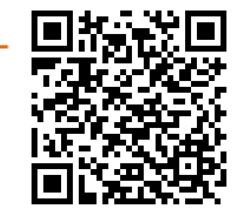

Management

\title{
SERVICE QUALITY OF PUBLIC AND PRIVATE SECTOR BANKS IN TIRUNELVELI DISTRICT
}

\author{
Dr. C. Eugine Franco ${ }^{* 1}$, G. Bright Jowerts ${ }^{2}$ \\ ${ }^{* 1}$ Associate Professor, PG \& Research Department of Commerce, St. Xavier's (Autonomous) \\ College, Palayamkottai, India \\ ${ }^{2}$ Assistant Professor in Commerce, St. Xavier's (Autonomous) College, Palayamkottai, India
}

DOI: https://doi.org/10.29121/granthaalayah.v5.i5(SE).2017.1966

\begin{abstract}
Service Quality of the banks referred as an obligation of all banks to fulfill the objectives and needs of the customers. Service quality in private sector banks is good compare to public sector banks. The various issues the banks are not able to provide immediate response to customers, service time duration is more, long queue deposit the money, waiting for long time, staff behavior is not good, especially public sector banks are not providing multitude services like payment of bills, payment of tax, Banc assurance etc. and problem relating to banking service such as bank statements, error in the statements are not provided immediate response to customers. The scope of this research is to identify the service quality of public and private sector banks in Tirunelveli district. This study only focuses on the dimensions of service quality i.e. reliability, assurance, tangibility, empathy and responsiveness. The study was done taking two types of banks such as public and private sector banks in Tirunelveli district into consideration. The survey was restricted to the bank customers in Tirunelveli district only. As the population size is infinite, 672 respondents are selected as sample among the population using stratified random sampling. The sample has been stratified as 528 from public sector bank customers and 144 from private sector bank customers in Tirunelveli district.
\end{abstract}

Keywords: Service Quality; Reliability; Assurance; Tangibility; Empathy And Responsiveness.

Cite This Article: Dr. C. Eugine Franco, and G. Bright Jowerts. (2017). "SERVICE QUALITY OF PUBLIC AND PRIVATE SECTOR BANKS IN TIRUNELVELI DISTRICT.” International Journal of Research - Granthaalayah, 5(5)SE, 42-52.

\section{Introduction}

SERVQUAL represents service quality as the discrepancy between a customer's expectations for a service offering and the customer's perceptions of the service received, requiring respondents to answer questions about both their expectations and their perceptions. SERVQUAL has been proposed as a useful instrument for diagnostic purposes. It has been found to effectively identify 
the gaps in the dimension and thus help the service organization to assess service quality and do the needful to bridge the GAP. Service quality is an approach to manage business processes in order to ensure full satisfaction of the customers which will help to increase competitiveness and effectiveness of the industry. Quality in service is very important especially for the growth and development of service sector business enterprises.

\section{Statement of the Problem}

Service Quality of the banks referred as an obligation of all banks to fulfill the objectives and needs of the customers. In General it is perused that, service quality in private sector banks is good compare to public sector banks. The various issues the banks are not able to provide immediate response to customers, service time duration is more, long queue deposit the money, waiting for long time, staff behavior is not good, especially public sector banks are not providing multitude services like payment of bills, payment of tax, Banc assurance etc. and problem relating to banking service such as bank statements, error in the statements are not provided immediate response to customers. Parking facility in banks is very poor compared to private sector banks. The biggest challenge today for the bank is to establish customers intimacy without which all other efforts towards operationed excellence are meaningless. The present need of banks is to have good relationship with customers by providing quality services to retain the existing and generate or acquire new customers. Thus, this study attempts to study the service quality of public and private sector banks in the present scenario.

\section{Scope of the Study}

The scope of this research is to identify the service quality of public and private sector banks in Tirunelveli district. This study only focuses on the dimensions of service quality i.e. reliability, assurance, tangibility, empathy and responsiveness. The study was done taking two types of banks such as public and private sector banks in Tirunelveli district into consideration. The survey was restricted to the bank customers in Tirunelveli district only.

\section{Objectives of the Study}

The study has the following objectives

i. To study the demographic profile of customers of public and private sector banks in Tirunelveli district.

ii. To study and compare the existing service quality dimensions in the Public and Private sector banks.

iii. To find out the problems faced by the customers in availing banking services.

\section{Methodology}

The methodology of the study is based on both primary data and secondary data. The primary data collected through well-framed and structured questionnaire to elicit the well-considered opinion of both public sector and private sector bank customers. Stratified random sampling method has been used to collect the responses from the customers of both public and private sector banks. 


\section{Sampling Design}

As the population size is infinite, 672 respondents are selected as sample among the population using stratified random sampling. The sample has been stratified as 528 from public sector bank customers and 144 from private sector bank customers in Tirunelveli district.

Table 1: Sampling of the Study

\begin{tabular}{|l|l|l|l|l|l|}
\hline Public Sector Banks & No. of Banks & Sample & Sub Total & Total \\
\hline Sl. No & Area & 34 & 3 & 162 & \\
\hline 1 & Rural & 3 & 198 & \\
\hline 2 & Semi-urban & 66 & 3 & 168 & \\
\hline 3 & Urban & 56 & $\mathbf{3}$ & $\mathbf{5 2 8}$ & $\mathbf{5 2 8}$ \\
\hline TOTAL & $\mathbf{1 7 6}$ & Sample & Sub Total & Total \\
\hline Private Sector Banks & No. of Banks & 3 & 57 & \\
\hline Sl. No & Area & 19 & 3 & 57 & \\
\hline 1 & Rural & 19 & 3 & 30 & \\
\hline 2 & Semi-urban & 10 & $\mathbf{3}$ & $\mathbf{1 4 4}$ & $\mathbf{1 4 4}$ \\
\hline 3 & Urban & $\mathbf{4 8}$ & Total Sample size & $\mathbf{6 7 2}$ \\
\hline TOTAL &
\end{tabular}

\section{Limitations of the Study}

In this research, 672 respondents are considered to suggest the five dimensions of service quality of banking in Tirunelveli district. Large sample of respondents may produce better results.

The service quality is a vast subject consisting of a number of dimensions. The most common five service quality dimensions namely, Tangibility, Reliability, Responsiveness, Assurance, and Empathy only were analyzed in the present study.

\section{Data Analysis and Interpretation}

Table 2: Age wise classification of Respondents

\begin{tabular}{|l|l|l|l|l|}
\hline \multirow{2}{*}{$\begin{array}{l}\text { S. } \\
\text { No }\end{array}$} & Age & \multicolumn{2}{|l|}{ Type of Banks } & \multirow{2}{*}{ Total } \\
\cline { 3 - 4 } & & $\begin{array}{l}\text { Public Sector } \\
\text { Banks }\end{array}$ & $\begin{array}{l}\text { Private Sector } \\
\text { Banks }\end{array}$ & \\
\hline 1. & Below 20 years & $59(11.2)$ & - & $59(8.8)$ \\
\hline 2. & 20-30 years & $172(32.6)$ & $65(45.1)$ & $237(35.3)$ \\
\hline 3. & $31-40$ years & $111(21.0)$ & $49(34.0)$ & $160(23.8)$ \\
\hline 4. & $41-50$ years & $73(13.8)$ & $14(9.7)$ & $87(12.9)$ \\
\hline 5. & $51-60$ years & $89(16.9)$ & $14(9.7)$ & $103(15.3)$ \\
\hline 6. & Above 60 years & $24(4.5)$ & $2(1.4)$ & $26(3.9)$ \\
\hline & Total & $\mathbf{5 2 8}(\mathbf{1 0 0})$ & $\mathbf{1 4 4}(\mathbf{1 0 0})$ & $\mathbf{6 7 2}(\mathbf{1 0 0})$ \\
\hline
\end{tabular}

Source: Primary data

(Parentheses indicates percentage) 
Table 2 shows that of the total 672 respondents, majority i.e 237 respondents ( 35.3 per cent) are in the age group of 20 to 30 years and the next majority 160 respondents ( 23.8 per cent) are in the age group of 31 to 40 years. Bank wise analysis reveals that among the customers of public sector banks, majority (32.6 per cent) of the respondents are in the age group of 20 to 30 years and in private sector banks, majority (45.1 per cent) of the respondents are in the age group of 20 to 30 years.

Table 3: Gender wise classification of Respondents

\begin{tabular}{|l|l|l|l|l|}
\hline Sl. & Gender & \multicolumn{2}{|l|}{ Type of Banks } & \multirow{2}{*}{ Total } \\
\cline { 3 - 4 } & & $\begin{array}{l}\text { Public Sector } \\
\text { Banks }\end{array}$ & $\begin{array}{l}\text { Private Sector } \\
\text { Banks }\end{array}$ & \\
\hline 1. & Male & $300(56.8)$ & $80(55.6)$ & $380(56.5)$ \\
\hline 2. & Female & $228(43.2)$ & $64(44.4)$ & $292(43.5)$ \\
\hline & Total & $\mathbf{5 2 8 ( 1 0 0 )}$ & $\mathbf{1 4 4}(\mathbf{1 0 0})$ & $\mathbf{6 7 2 ( 1 0 0 )}$ \\
\hline
\end{tabular}

Source: Primary data

(Parentheses indicates percentage)

From table 3 it could be inferred that of the total 672 respondents, 380 respondents (56.5 per cent) are male and the remaining 292 respondents (43.5 per cent) are female. Bank wise analysis reveals that among the customers of public sector banks, majority (56.8 per cent) of the respondents are male and in private sector banks, majority (55.6 per cent) of the respondents are male.

Table 4: Kind of account maintain in the bank

\begin{tabular}{|l|l|l|l|}
\hline \multirow{2}{*}{$\begin{array}{l}\text { Kind of account } \\
\text { maintain in the bank }\end{array}$} & \multicolumn{2}{|l|}{ Type of Banks } & \multirow{2}{*}{ Total } \\
\cline { 2 - 3 } & $\begin{array}{l}\text { Public Sector } \\
\text { Banks }\end{array}$ & $\begin{array}{l}\text { Private Sector } \\
\text { Banks }\end{array}$ & \\
\hline Savings & $432(81.8)$ & $104(72.2)$ & $536(79.8)$ \\
\hline Current & $25(4.7)$ & $18(12.5)$ & $43(6.4)$ \\
\hline Loan account & $9(1.7)$ & $2(1.4)$ & $11(1.6)$ \\
\hline $\begin{array}{l}\text { Both savings and loan } \\
\text { account }\end{array}$ & $7(1.3)$ & $3(2.1)$ & $10(1.5)$ \\
\hline $\begin{array}{l}\text { Both current and loan } \\
\text { account }\end{array}$ & $41(7.8)$ & $14(9.7)$ & $55(8.2)$ \\
\hline Credit card & $7(1.3)$ & $2(1.4)$ & $9(1.3)$ \\
\hline Demat account & $7(1.3)$ & $1(0.7)$ & $8(1.2)$ \\
\hline Total & $\mathbf{5 2 8 ( 1 0 0 )}$ & $\mathbf{1 4 4 ( 1 0 0 )}$ & $\mathbf{6 7 2 ( 1 0 0 )}$ \\
\hline
\end{tabular}

Source: Primary data

(Parentheses indicates percentage)

Table 4 clearly reveals that out of the total 672 respondents, 536 respondents ( 79.8 per cent) have savings account and 55 respondents (8.2 per cent) have both current and loan account. Bank wise analysis reveals that among the customers of public sector banks, majority ( 81.8 per cent) of the respondents have savings account and in private sector banks, majority (72.2 per cent) of the respondents have savings account. 


\section{Service quality Gap in Public Sector Banks in Tirunelveli District}

The following table shows the service quality gap in public sector banks in Tirunelveli district.

Table 5: Service quality Gap in Public Sector Banks in Tirunelveli District

\begin{tabular}{|c|c|c|c|}
\hline Statements & $\begin{array}{l}\text { Expectation } \\
\text { Mean }\end{array}$ & $\begin{array}{l}\text { Perception } \\
\text { Mean }\end{array}$ & $\begin{array}{l}\text { Service } \\
\text { quality gap }\end{array}$ \\
\hline Tangibility & 3.8885 & 2.8645 & 1.0240 \\
\hline $\begin{array}{l}\text { Adequate } \\
\text { facilities }\end{array}$ & 4.3144 & 2.9931 & 1.3213 \\
\hline $\begin{array}{l}\text { Physical appearance of the staff } \\
\text { is professional }\end{array}$ & 3.9261 & 2.6875 & 1.2386 \\
\hline Visually appealing features & 3.7292 & 2.8333 & 0.8959 \\
\hline Location is easily accessible & 3.8958 & 2.5486 & 1.3472 \\
\hline Location is free from pollution & 3.9931 & 2.8889 & 1.1042 \\
\hline $\begin{array}{l}\text { Bank uses latest technologies in } \\
\text { providing services }\end{array}$ & 3.7639 & 2.9028 & 0.8611 \\
\hline $\begin{array}{l}\text { Vehicle parking facility is } \\
\text { available }\end{array}$ & 3.8403 & 2.7431 & 1.0972 \\
\hline Information is easily available & 3.8731 & 3.0972 & 0.7759 \\
\hline $\begin{array}{l}\text { Company is having a } \\
\text { memorable advertisement }\end{array}$ & 3.7847 & 3.0833 & 0.7014 \\
\hline $\begin{array}{l}\text { Beautiful elevation of the office } \\
\text { building }\end{array}$ & 3.7652 & 2.8681 & 0.8971 \\
\hline Reliability & 3.8653 & 2.9680 & 0.8973 \\
\hline Get things right at the first time & 3.9186 & 2.9375 & 0.9811 \\
\hline $\begin{array}{l}\text { Provide services at time } \\
\text { promises to do so it }\end{array}$ & 3.8056 & 2.9306 & 0.875 \\
\hline Insists on error free records & 3.8333 & 3.0278 & 0.8055 \\
\hline $\begin{array}{l}\text { Bank has competitive pricing } \\
\text { compared to others }\end{array}$ & 3.8542 & 3.0139 & 0.8403 \\
\hline $\begin{array}{l}\text { Provision of documentary } \\
\text { evidences for banking services }\end{array}$ & 3.9148 & 2.9306 & 0.9842 \\
\hline Responsiveness & 4.0369 & 2.8694 & 1.1675 \\
\hline $\begin{array}{l}\text { Staff tell exactly when the } \\
\text { services will be performed }\end{array}$ & 4.2708 & 3.0833 & 1.1875 \\
\hline $\begin{array}{l}\text { Staff are prompt in responding } \\
\text { to questions and queries }\end{array}$ & 4.0069 & 2.6944 & 1.3125 \\
\hline $\begin{array}{l}\text { Front office staff responding to } \\
\text { phone calls instantaneously }\end{array}$ & 3.9318 & 2.8472 & 1.0846 \\
\hline Staff is willing to help anytime & 3.9583 & 2.7778 & 1.1805 \\
\hline Organised time table & 4.0170 & 2.9444 & 1.0726 \\
\hline Assurance & 3.9863 & 2.9999 & 0.9864 \\
\hline $\begin{array}{l}\text { Employees are trustworthy and } \\
\text { honest }\end{array}$ & 3.9931 & 2.8611 & 1.132 \\
\hline
\end{tabular}




\begin{tabular}{|c|c|c|c|}
\hline $\begin{array}{l}\text { Employees in banks have } \\
\text { knowledge and competence to } \\
\text { solve customer's problem }\end{array}$ & 3.9489 & 2.9722 & 0.9767 \\
\hline Bank is widely known & 3.8681 & 3.1875 & 0.6806 \\
\hline Bank is well liked & 3.8689 & 2.8194 & 1.0495 \\
\hline $\begin{array}{l}\text { Bank is unique compared to } \\
\text { others }\end{array}$ & 3.9394 & 2.9444 & 0.995 \\
\hline $\begin{array}{l}\text { Bank Staff give assurance as to } \\
\text { deliverance of the services }\end{array}$ & 4.1477 & 3.1181 & 1.0296 \\
\hline $\begin{array}{l}\text { Data revealed by customers are } \\
\text { kept confidential }\end{array}$ & 4.0000 & 3.0208 & 0.9792 \\
\hline $\begin{array}{l}\text { Bank staff give assurance with } \\
\text { regard to their efficient service }\end{array}$ & 4.1250 & 3.0764 & 1.0486 \\
\hline Empathy & 3.9920 & 3.0097 & 0.9823 \\
\hline $\begin{array}{l}\text { Customers get individual } \\
\text { attention }\end{array}$ & 4.0455 & 3.0556 & 0.9899 \\
\hline $\begin{array}{l}\text { Bank has its customer's best } \\
\text { interest in heart }\end{array}$ & 3.9583 & 2.9306 & 1.0277 \\
\hline Client friendly service hours & 4.2197 & 3.3056 & 0.9141 \\
\hline $\begin{array}{l}\text { Bank staff have concern and } \\
\text { they understand customer } \\
\text { problems }\end{array}$ & 3.8655 & 2.9931 & 0.8724 \\
\hline $\begin{array}{l}\text { Seek to understand customer's } \\
\text { need and their problem }\end{array}$ & 3.8712 & 2.7639 & 1.1073 \\
\hline
\end{tabular}

Source: Computed data

It is clear from the table 5 that among the customers of public sector banks in Tirunelveli district, the mean scores of expectations are high and ranged from 3.7292 for (item 3: Visually appealing features) to 4.3144 for (item 1: Adequate infrastructural facilities). Among the five dimensions, the highest expectation related to the responsiveness dimensions (dimension's mean score $=$ 4.0369) and the lowest expectation related to the reliability dimension (dimension's mean score $=3.8653)$.

The mean score of the perceptions ranged from 2.6875 for (item 2: Physical appearance of the staff is professional) to 3.3056 for (item 31: Client friendly service hours). Among the five dimensions of quality, the highest perception related to the empathy dimension (dimension's mean score $=3.0097$ ) and the lowest perception related to the tangibility dimension (dimension's mean score $=2.8645$ ).

The gap score for each item and dimension was computed by subtracting the expectation score from the perception score. Table shows that the highest gap of the quality relates to the responsiveness dimension (gap mean score $=1.1675$ ), and there is a considerable gap between the customers' expectations and perceptions. The lowest gap of the quality relates to the reliability dimension $($ gap mean score $=0.8973)$. 


\section{Service quality Gap in Private Sector Banks in Tirunelveli District}

The following table shows the service quality gap in private sector banks in Tirunelveli district.

Table 6: Service quality Gap in Private Sector Banks in Tirunelveli District

\begin{tabular}{|c|c|c|c|}
\hline Statements & $\begin{array}{l}\text { Expectation } \\
\text { Mean }\end{array}$ & $\begin{array}{l}\text { Perception } \\
\text { Mean }\end{array}$ & $\begin{array}{l}\text { Service } \\
\text { quality gap }\end{array}$ \\
\hline Tangibility & 3.7223 & 3.2159 & 0.5064 \\
\hline $\begin{array}{l}\text { Adequate } \\
\text { facilities }\end{array}$ & 4.2986 & 3.5170 & 0.7816 \\
\hline $\begin{array}{l}\text { Physical appearance of the staff } \\
\text { is professional }\end{array}$ & 3.6597 & 3.1174 & 0.5423 \\
\hline Visually appealing features & 3.6136 & 2.8864 & 0.7272 \\
\hline Location is easily accessible & 3.5227 & 3.3030 & 0.2197 \\
\hline Location is free from pollution & 3.7045 & 2.9299 & 0.7746 \\
\hline $\begin{array}{l}\text { Bank uses latest technologies in } \\
\text { providing services }\end{array}$ & 3.7481 & 3.1553 & 0.5928 \\
\hline $\begin{array}{l}\text { Vehicle parking facility is } \\
\text { available }\end{array}$ & 3.4867 & 3.2860 & 0.2007 \\
\hline Information is easily available & 3.8333 & 3.4091 & 0.4242 \\
\hline $\begin{array}{l}\text { Company is having a } \\
\text { memorable advertisement }\end{array}$ & 3.5928 & 3.2822 & 0.3106 \\
\hline $\begin{array}{l}\text { Beautiful elevation of the office } \\
\text { building }\end{array}$ & 3.7639 & 3.2727 & 0.4912 \\
\hline Reliability & 3.7956 & 3.3204 & 0.4752 \\
\hline Get things right at the first time & 3.8542 & 3.4167 & 0.4375 \\
\hline $\begin{array}{l}\text { Provide services at time } \\
\text { promises to do so it }\end{array}$ & 3.6913 & 3.2140 & 0.4773 \\
\hline Insists on error free records & 3.7443 & 3.1856 & 0.5587 \\
\hline $\begin{array}{l}\text { Bank has competitive pricing } \\
\text { compared to others }\end{array}$ & 3.8201 & 3.3333 & 0.4868 \\
\hline $\begin{array}{l}\text { Provision of documentary } \\
\text { evidences for banking services }\end{array}$ & 3.8681 & 3.4527 & 0.4154 \\
\hline Responsiveness & $\mathbf{3 . 9 3 3 2}$ & 3.2026 & 0.7306 \\
\hline $\begin{array}{l}\text { Staff tell exactly when the } \\
\text { services will be performed }\end{array}$ & 4.1117 & 3.3125 & 0.7992 \\
\hline $\begin{array}{l}\text { Staff are prompt in responding } \\
\text { to questions and queries }\end{array}$ & 3.7633 & 3.2102 & 0.5531 \\
\hline $\begin{array}{l}\text { Front office staff responding to } \\
\text { phone calls instantaneously }\end{array}$ & 3.9028 & 3.0038 & 0.899 \\
\hline Staff is willing to help anytime & 3.9508 & 3.2367 & 0.7141 \\
\hline Organised time table & 3.9375 & 3.2500 & 0.6875 \\
\hline Assurance & 3.8699 & 3.3167 & 0.5532 \\
\hline $\begin{array}{l}\text { Employees are trustworthy and } \\
\text { honest }\end{array}$ & 3.8239 & 3.2595 & 0.5644 \\
\hline
\end{tabular}




\begin{tabular}{|c|c|c|c|}
\hline $\begin{array}{l}\text { Employees in banks have } \\
\text { knowledge and competence to } \\
\text { solve customer's problem }\end{array}$ & 3.9296 & 3.1534 & 0.7762 \\
\hline Bank is widely known & 3.5811 & 3.4375 & 0.1436 \\
\hline Bank is well liked & 3.8111 & 3.3295 & 0.4816 \\
\hline $\begin{array}{l}\text { Bank is unique compared to } \\
\text { others }\end{array}$ & 3.7986 & 3.5379 & 0.2607 \\
\hline $\begin{array}{l}\text { Bank Staff give assurance as to } \\
\text { deliverance of the services }\end{array}$ & 4.0000 & 3.1951 & 0.8049 \\
\hline $\begin{array}{l}\text { Data revealed by customers are } \\
\text { kept confidential }\end{array}$ & 3.9878 & 3.3466 & 0.6412 \\
\hline $\begin{array}{l}\text { Bank staff give assurance with } \\
\text { regard to their efficient service }\end{array}$ & 4.0278 & 3.2746 & 0.7532 \\
\hline Empathy & 3.9920 & 3.4583 & $\mathbf{0 . 5 3 3 7}$ \\
\hline $\begin{array}{l}\text { Customers get individual } \\
\text { attention }\end{array}$ & 4.0455 & 3.1970 & 0.8485 \\
\hline $\begin{array}{l}\text { Bank has its customer's best } \\
\text { interest in heart }\end{array}$ & 3.9583 & 3.3030 & 0.6553 \\
\hline Client friendly service hours & 4.2197 & 3.8049 & 0.4148 \\
\hline $\begin{array}{l}\text { Bank staff have concern and } \\
\text { they understand customer } \\
\text { problems }\end{array}$ & 3.8655 & 3.5739 & 0.2916 \\
\hline $\begin{array}{l}\text { Seek to understand customer's } \\
\text { need and their problem }\end{array}$ & 3.8712 & 3.4129 & 0.4583 \\
\hline
\end{tabular}

Source: Computed data

It is clear from the table 6 that the mean scores of expectations are high and ranged from 3.4867 for (item 7: Vehicle parking facility is available) to 4.2986 for (item 1: Adequate infrastructural facilities). Among the five dimensions, the highest expectation related to the empathy dimensions (dimension's mean score $=3.9920$ ) and the lowest expectation related to the tangibility dimension (dimension's mean score $=3.7223$ ).

The mean score of the perceptions ranged from 2.8864 for (item 3: Visually appealing features) to 3.8049 for (item 31: Client friendly service hours). Among the five dimensions of quality, the highest perception related to the empathy dimension (dimension's mean score $=3.4583$ ) and the lowest perception related to the responsiveness dimension (dimension's mean score $=3.2026$ ).

The gap score for each item and dimension was computed by subtracting the expectation score from the perception score. Table shows that the highest gap of the quality relates to the responsiveness dimension (gap mean score $=0.7306$ ), and there is a considerable gap between the customers' expectations and perceptions. The lowest gap of the quality relates to the reliability dimension (gap mean score $=0.4752$ ). 
Table 7: Ranking of problems faced by customers of public sector banks while availing banking services

\begin{tabular}{|l|l|l|l|l|}
\hline Sl. No & Problems & Total Score & Average & Rank \\
\hline 1. & Waiting for a long time & 29976 & 56.77 & I \\
\hline 2. & Unsatisfactory services & 28095 & 53.21 & II \\
\hline 3. & Inadequate staff & 27845 & 52.74 & III \\
\hline 4. & Unfriendly staff & 26337 & 49.88 & V \\
\hline 5. & $\begin{array}{l}\text { Lack of proper direction by bank } \\
\text { staff }\end{array}$ & 26822 & 50.79 & IV \\
\hline 6. & Inadequate infrastructure & 25977 & 49.19 & VI \\
\hline 7. & Exaggeration of benefits & 24223 & 45.88 & IX \\
\hline 8. & Imprompt service by the staff & 24400 & 46.21 & VIII \\
\hline 9. & $\begin{array}{l}\text { No proper and timely reminders } \\
\text { No complete information about } \\
\text { banking transactions }\end{array}$ & 2027930 & 38.39 & X \\
\hline 10. & 47.22 & VII \\
\hline
\end{tabular}

Source: Primary data

It is observed from the Table 7 that "Waiting for a long time" has been ranked as the first problem faced by customers of public sector banks while availing banking service, unsatisfactory services has been ranked as second, inadequate staff in third position, lack of proper direction by bank staff is ranked as fourth, unfriendly staff is ranked as fifth, inadequate infrastructure is ranked as sixth, no complete information about banking transactions is ranked as seventh, imprompt service by the staff is ranked as eighth, exaggeration of benefits is ranked as nineth followed by no proper and timely reminders ranked as tenth position.

Table 8: Ranking of problems faced by customers of private sector banks while availing banking

\begin{tabular}{|l|l|l|l|l|}
\hline Sl. No & Problems & Total Score & Average & Rank \\
\hline 1. & Waiting for a long time & 7480 & 51.94 & III \\
\hline 2. & Unsatisfactory services & 7674 & 53.29 & I \\
\hline 3. & Inadequate staff & 6896 & 47.89 & IX \\
\hline 4. & Unfriendly staff & 7645 & 53.09 & II \\
\hline 5. & $\begin{array}{l}\text { Lack of proper direction by bank } \\
\text { staff }\end{array}$ & 7361 & 51.12 & IV \\
\hline 6. & Inadequate infrastructure & 6946 & 48.24 & VII \\
\hline 7. & Exaggeration of benefits & 6974 & 48.43 & VI \\
\hline 8. & Imprompt service by the staff & 7011 & 48.68 & V \\
\hline 9. & No proper and timely reminders & 6929 & 48.12 & VIII \\
\hline 10. & $\begin{array}{l}\text { No complete information about } \\
\text { banking transactions }\end{array}$ & 6606 & 45.87 & X \\
\hline
\end{tabular}

Source: Primary data

It is observed from the Table 8 that "Unsatisfactory services" has been ranked as the first problem faced by customers of private sector banks while availing banking service, unfriendly staff has been ranked as second, waiting for a long time in third position, lack of proper direction 
by bank staff is ranked as fourth, imprompt service by the staff is ranked as fifth, exaggeration of benefits is ranked as sixth, inadequate infrastructure is ranked as seventh, no proper and timely reminders is ranked as eighth, inadequate staff is ranked as ninth followed by no complete information about banking transactions ranked as tenth position.

\section{Suggestions}

- The customer's perception of tangibility dimension of service quality is lower in public sector banks. So the public sector banks may take steps to improve latest technologies in providing services, adequate infrastructural facilities and location is easily accessible.

- The customer's perception of responsiveness dimension of service quality is lower in private sector banks. So the private sector banks staff should be prompt in responding to questions and queries of customers, staff should be willing to help anytime and may follow organised time table.

- Banks must train all the employees in the areas of customer care, customer approach, body language, customer communication, customer need assessment and compliant management. This will help to pave the way for maintaining cordial relationship and improve the quality of services.

- Bank should maintain good relationship with customers by providing necessary and needed services to the customers.

- ATM services must be provided with accessibility of the customers, that is ATM centers should be within a short distance and it will improve the quality of services.

- Bank employees have to be trained especially in the rural branches to improve the quality of banking services.

\section{Conclusion}

Banks are providing voluminous services to their customers' in an effective and efficient way due to heavy competition among banks and to sustain their business in the banking industry. The performance of bank always depends on quality of services they provide to their customers. This study has focused to assess and evaluate quality aspects in various banking services and their approaches to the customers. Universally accepted instruments to assess the service quality in SERVQUAL were the base to frame variables to assess the service quality in banks on those five dimensions (Tangibles, Assurance, Reliability, Responsiveness and Empathy). This study brought to light the fact that the customers were very much satisfied on the service quality of the banks in the region but at the same time they expect a lot more from the banks in the present scenario of technological developments in banks. Hence, this study will pave way to further research to explore this mechanism in depth to provide quality banking services to facilitate the customers, the society and the economy as a whole.

\section{References}

[1] Cronin, J.J. and S.A. Taylor, "Measuring Service Quality: A Re-Examination and Extension", Journal of Marketing, 1992, Vol. 56. 
[2] Golden, S. A. R., \& Regi, S. B. (2015). Satisfaction of Customers towards User Friendly Technological Services offered by Public and Private Sector banks at Palayamkottai, Tirunelveli District. International Journal of Research, 2(3), 775-787.

[3] Golden, S. A. R. (2015). Regional Imbalance affecting quality of e-banking services with special reference to Tuticorin District- An Analysis. International Journal of Research, 2(3), 788-799.

[4] Parasuraman,;V. A. Zeithaml,; and L.L. Berry., "Reassessment of Expectations as a Comparison Standard in Measuring Service Quality - Implications for Further Research", Journal of Marketing, 1994, Vol. 58, No.1.

Ananth, A. and Ramesh, R., "Service Quality Gap Analysis in Private Sector Banks a Customers Perspective”, Internationally Indexed Journal, 2011, Vol.II, Issue.1.

[5] Regi, S. B., \& Golden, S. A. R. (2014). Customer Preference Towards Innovative Banking Practices Available In State Bank Of India At Palayamkottai. Sankhya International Journal Of Management And Technology, 3(11 (A)), 31-33.

[6] Regi, S. B., Golden, S. A. R., \& Franco, C. E. (2014). A STUDY ON IMPACT OF INFORMATION TECHNOLOGY (IT) IN MODERN BANKING SECTOR. Golden Research Thoughts, 3(9), 1-4.

[7] Regi, S. B., Golden, S. A. R., \& Franco, C. E. (2014). EMPLOYEE PERCEPTION TOWARDS EFFECTIVENESS OF HR PRACTICES IN PUBLIC SECTOR BANKS IN TIRUNELVELI DISTRICT. Tactful Management Research Journal, 2(6), 1-4.

[8] Zeithamal, V.A., A. Parasuraman and L.L. Berry, "Delivering Quality Service: Balancing Customer Perceptions, and Experiences", Free Press, New York, 1990. 